\title{
PENGARUH KEMANDIRIAN BELAJAR DAN SARANA PRASARANA PEMBELAJARAN TERHADAP HASIL BELAJAR SISWA
}

\author{
Anisa Nur Qomariyah', Siti Sri Wulandari² \\ Fakultas Ekonomi, Universitas Negeri Surabaya \\ email: ${ }^{1}$ anisa.17080314019@mhs.unesa.ac.id \\ email: ${ }^{2}$ sitiwulandari@unesa.ac.id
}

\begin{abstract}
This research aims to determine the effect of learning independence and learning infrastructure on the learning scores of class XI students at SMK Negeri 10 Surabaya. The population in this study was 60 students in class XI in the field of Office Governance Automation in 2020/2021. The sample of this research is 52 students. The population in this study was determined based on probability sampling with random sampling. This research uses quantitative research methods. Data collection using interview techniques, documentation and questionnaires. The distribution of questionnaires in this study was online and interviews were conducted directly with teachers of Public Relations and Protocol subjects. By using the classical assumption test method using normality test, multicollinearity test, heteroscedasticity test and using multiple linear analysis and also hypothesis testing, namely $t$ test, $f$ test and coefficient of determination $\left(R^{2}\right)$ test. Based on the results of statistical data analysis using the SPSS 23 application, it can be concluded that (1) learning independence can have a significant influence on student learning outcomes with a significant value of $0.017<0.05$. (2) learning facilities and infrastructure have a significant impact on the value of student learning by $0.006<0.05$. (3) learning independence and learning facilities and infrastructure simultaneously have a significant influence on the dependent variable, namely student learning outcomes with a significance value of $0.012<0.05$.
\end{abstract}

Keywords: Independent learning, learning facilities and infrastructure, student learning outcomes.

\begin{abstract}
Abstrak: Penelitian ini bertujuan untuk mengetahui pengaruh kemandirian belajar dan sarana prasarana pembelajaran pada nilai dari belajar siswa kelas XI SMK Negeri 10 Surabaya. Populasi pada penelitian ini kelas XI bidang studi Otomatisasi Tata Kelola Perkantoran tahun 2020/2021 sebanyak 60 siswa. Sampel penelitian ini sebanyak 52 siswa. Populasi dalam penelitian ini ditentukan berdasarkan probability sampling dengan random sampling. Penelitian ini menggunakan metode penelitian kuantitatiff. Pengumpulan data memakai teknik wawancara, dokumentasi dan angket. Penyebaran angket pada penelitian ini secara online dan wawancara dilakukan langsung dengan guru mata pelajaran Humas dan Keprotokolan. Dengan memakai metode uji asumsi klasik yakni memakai uji normalitas, uji multikolinieritas, uji heteroskedastisitas dan memakai analisis linier berganda dan juga uji hipotesis yakni uji t, uji f dan uji koefesien determinasi $\left(\mathrm{R}^{2}\right)$. Berdasarkan hasil analisis data statistic menggunakan aplikasi SPSS 23 dapat disimpulkan yaitu (1) kemandirian belajar dapat memberikan pengaruh secara signifikan pada hasil belajar siswa dengan nilai signifikannya sebesar $0,017<0,05$. (2) sarana dan prasarana pembelajaran berdampak signifikan kepada nilai dari belajar siswa sebesar 0,006 < 0,05. (3) kemandirian belajar dan sarana dan prasarana belajar secara simultan mempunyai pengaruh signifikan terhadap variabel terikatnya yaitu hasil belajar siswa dengan nilai signifikasinya sebesar $0,012<0,05$
\end{abstract}

Kata kunci: Kemandirian belajar, sarana dan prasarana pembelajaran, hasil belajar siswa. 


\section{PENDAHULUAN}

Upaya guna penambahan quality setiap proses dan hasil dari belajar siswa perlu memperoleh tingkat dan jenjang pendidikan untuk memperoleh sumber daya manusia yang mempunyai quality. Hal ini menjadi tanggung jawab seluruh pendidik, oleh sebab itu peran pendidik sangat menjadi penentuan, sebab dialah pendidik yang secara langsung ikut serta dalam pekerjaan pembinaan siswa melalui proses pembelajaran.

Belajar adalah proses berinteraksi dengan diri individu dengan individu agar mampu merubah perilaku. Menurut McClelland \& Cameron (dalam Firdausy et al., 2019) kemandirian atau pengaturan diri dalam belajar sangat penting bahkan sejak anak-anak. Dalam penelitian Widiartini \& Sudirtha (2019) kemandirian belajar adalah kemampuan seseorang untuk memahami dan mengontrol proses pembelajaran. Menurut Saragih (2017) murid yang memiliki sikap lebih mandiri akan lebih berani memberi putusan pada perihal-perihal yang bersangkutan dengan dirinya sendiri dan terbebas dari faktor pengaruh orang lainnya, dapat memiliki inisiatif dan mengembangkan kreatifitas dan juga memberi rangsangan dengan tujuan berprestasi lebih baik. Oleh karena itu, siswa harus melaksanakan kegiatan pembelajaran terstruktur dan pembelajaran mandiri dilakukan secara mandiri (secara individu maupun kelompok), dan kedua kegiatan tersebut tidak memerlukan keterlibatan pribadi guru. Menurut Suratman et al., (2020) guru adalah yang factor dominan dalam kaitannya dengan peningkatan kualitas pendidikan. Menurut Ilomo \& Mlavi (2016) bimbingan dari guru ialah salah satu penyebab yang membuat murid dapat meningkatkan pembelajarannya. Untuk itu, guru dan siswa harus saling bekerja sama agar mencapai suatu tujuan yang diinginkan.

Menurut CHENG (2011) belajar mandiri adalah kegiatan multi-dimensi yang mengaitkan kognisi, emosi, tindakan, dan lingkungan individu, perlu tenaga pendidik memberi nasehat kepada siswa tentang penilaian diri, penetapan tujuan, strategi pembelajaran, motivasi dan pemantauan. Semua sekolah ingin siswanya belajar lebih baik untuk mendapatkan hasil berpendidikan tinggi. Persyaratan pembelajaran ini menuntut siswa supaya belajar lebih mandiri, memanage waktu dan melakukan kegiatan dalam belajar secara disiplin lebih terkonsentrasi dan intensif agar siswa bisa tampil lebih produktif dan inovasi. Perlengkapan utama yang diperlukan siswa dalam beradaptasi dengan kebutuhan ini mampu dan mengatur kegiatan dalam belajar, melakukan kontrol keterampilan perilaku, dan memahami tujuan, arahan dan sumber pendukung pembelajaran. Belajar adalah mengubah perilaku pribadi siapa yang mempelajarinya. Perubahan perilaku adalah akuisisi yang menjadi acuan hasil dari belajar. Aspek dalam perubahan itu berpedoman pada taksonomi dengan visi edukasi yang dijabarkan oleh Bloom, Simpson, dan Harrow yang melingkupi aspek kognitif, afektif dan psikomotorik pendapat dari (Purwanto, 2008).

Dalam penelitilian Othman \& Leng (2011) prestasi akademik berarti seberapa baik nilai siswa dalam ujian tengah semester di sekolah. Hal tersebut telah dinilai oleh guru, siswa dan diwakili oleh nilai rata-rata dari setiap mata pelajaran yang dievaluasi nilai siswa ujian tengah semester. Diungkapkan Sutrisno \& Siswanto (2016) lewat hasil dari belajar dapat terungkap secara holistik penjabaran capaian-capaian murid sesudah melewati proses pembelajaran. Wujud faktual hasil dari pembelajaran siswa di SMK dapat dilihat dari diadakannya nilai tugas, ulangan harian, ulangan tengah semester, ulangan akhir semester dan Uji Kompetensi Keahlian (UKK) Praktik Kejuruan.

Berdasarkan wawancara peneliti kepada tenaga pendidik mata pelajaran Humas dan Keprotokolan di SMK Negeri 10 Surabaya menyimpulkan jika minimnya tingkat kemandirian dalam study siswa khususnya kelas XI. Hal tersebut dapat disajikan pada saat pembelajaran siswa cenderung pasif, guru sudah memberikan 
media pembelajaran yang menarik dan cara mengajar agar siswa aktif sudah dilakukan. Tetapi apa yang diberikan guru pada saat pembelajaran membuat siswa masih banyak yang kurang tanggung jawab terhadap tugas yang diberikan tidak tepat waktu dalam menyelesaikannya, bolos sekolah dengan tidak ada alasan, tidak menyelesaikan tugas rumah yang ditanggung jawabkan, dan kurangnya percaya diri kepada potensi yang dipunyai. Dengan adanya permasalahan tersebut, pada saat pelaksanaan ulangan (harian, semester) beberapa siswa masih ada yang mencontek.

Pendapat dari Saragih (2017) sesuai dari kemandirian belajar, siswa dapat belajar memahami materi dari mata pelajaran sesuai dari kemampuan sendiri tanpa ada tekanan dari tenaga pendidik atau paksaan orang tua, sehingga siswa lebih aktif ketika belajar. Tirtarahardja dan La Sulo (2005) menyimpulkan jika kemandirian dalam study merupakan kegiatan dari study yang pelaksanaannya condong untuk disupport dari keinginan diri sendiri, keputusan diri sendiri dan tanggung jawab diri sendiri. Kemandirian dapat mensupport insan mencapai prestasi dan kreativitas. Menurut Tahar (dalam Wirayat dkk, 2019) mengatakan, "kemandirian belajar ialah kesiapan dari individu masing-masing yang memiliki kemauan dan kemampuan dalam study melalui keinginan dirinya sendiri, melalui maupun tidak adanya pertolongan dari faktor lainnya ketika hal pemilihan tujuan dari belajar, metode dari belajar, dan evaluasi hasil dari belajar. Kemandirian belajar murid ialah sejauh apa dia dalam belajar, proses murid mampu ikut memberi putusan dari tujuan, materi dan pembelajaran pengalaman, dan evaluasi pembelajaran menurut (Mulyono, 2017). Belajar mandiri menurut Balapumi \& Aitken (2012) adalah pembelajaran yang searah, dikendalikan dan pengaturan proses pembelajaran mereka semata-mata dipandu dan dikelola oleh peserta didik. Sikap mandiri akan jauh lebih berani ketika memberi keputusan perihal- perihal yang bersinggungan dengan dirinya bebas dengan diri sendiri, tidak akan dipengaruhi oleh orang-orang lain, mampu memiliki inisiatif, dalam melakukan pegembangan pada kreativitas murid dan memajukan prestasi yang lebih baik.

Kualitas lingkungan ditentukan oleh ketersediaan sarana, prasarana dan sumber daya Chepkonga (2017). Menurut Widodo (2017) menyatakan bahwa "Sarana dan prasarana dalam kegiatan belajar dapat sangat menjadi penentu dalam keberhasilan belajar karena murid diwajibkan untuk bisa menggali sumber dari study sendiri hingga terdapat kecukupan alat ataupun perlengkapan pemberi dukungan menjadi sesuatu hal yang sangat menjadi penentuan berhasil tidaknya dalam belajarnya. Fasilitas belajar menurut Sobandi et al., (2020) adalah segala fasilitas yang secara langsung mampu dipakai ketika progres pembelajaran dalam mencapai visi dari pembelajaran yang direncanakan. Menurut Hamalik (dalam Alfaruq et al., 2020) sarana dan prasarana ialah seluruh bentuk perantara yang digunakan orang untuk memberikan gagasan, hingga gagasan itu dapat tersampaikan kepada penerima. Tiap mata pelajaran memiliki karakter yang berbeda-beda. Oleh sebabnya, setiap mata pelajaran membutuhkan fasilitas belajar yang berbeda. Di kelas, guru tentunya membutuhkan sarana dan prasarana untuk mendukungnya, sehingga proses pembelajaran bisa berlangsung dengan lancar. Melalui alat pembelajaran yang cukup tidak hanya secara lisan tapi juga materi yang bisa menyampaikan secara tertulis dan berlatih dengan sarana prasarana yang sudah ada.

$$
\text { Kondisi sarana prasarana }
$$

pembelajaran yang ada di kelas XI OTKP SMK Negeri 10 Surabaya, dimana kenyamanan, kelengkapan dan adanya sarana prasarana pembelajaran di sekolah kurang memenuhi standar. Di beberapa kelas masih terkendala kipas angin yang rusak, ada juga yang di beberapa kelas kipas angin yang tidak dapat berputar, sehingga siswa di kelas mengalami penurunan konsentrasi dalam 
pembelajaran. Hal tersebut membuat siswa kurang dalam memahami sesuai apa yang diterangkan oleh guru, LCD disediakan tetapi beberapa terdapat kelas yang tidak bisa digunakan, problem itu menghambat kinerja guru ketika menjelaskan materi dan menghambat siswa dalam pemahaman materi, serta bahan ajar yang terbatas. Hal-hal tersebut sangat menghambat pembelajaran siswa, maka dari itu sarana prasarana yang lengkap, mewadahi dan dapat digunakan oleh siswa sangat menunjang pembelajaran siswa.

Berdasarkan hasil penelitian Widodo (2017) tentang dampak kemandirian dalam proses belajar terhadap nilai belajar praktek pengantar ekonomi dan bisnis menyimpulkan jika kemandirian study berdampak pada nilai belajar praktek pengantar ekonomi dan bisnis. Sedangkan menurut Faisal et al., (2019) ada dampak kemandirian dalam proses study dan pemaksimalan fasilitas dari belajar kepada nilai belajar dari biologi murid kelas XII MIA di SMAN 16 Makassar. Didukung juga oleh Alfaruq et al., (2020) pada penelitiannya juga menyatakan yang sama yaitu adanya dampak positif sarana prasarana bengkel kepada hasil belajar murid TKR SMK Tunas Bangsa Mijen.

Sesuai dengan latar belakang di atas, maka penting apabila riset tentang kedua variabel yang digunakan, yakni tingkat kemandirian dalam belajar dan sarana prasarana menjadi variabel bebas yang akan diselidiki tentang korelasinya dengan nilai dari belajar humas dan keprotokolan sebagai

\section{METODOLOGI PENELITIAN}

Ada beberapa jenis hubungan antar variabel dalam penelitian ilmiah salah satunya dalam penelitian ini adalah menggunakan jenis hubungan simetris, terjadi ketika ada dua variabel yang berhubungan secara fungsional. Hubungan dalam penelitian in digunakan variabel yang mampu mempengaruhi dan variabel terpengaruh. Variabel independen atau variabel bebas yang termasuk dalam riset ini yaitu kemandirian dalam belajar dan sarana prasarana pembelajaran. Sedangkan variabel variabel tak bebas. Hasil yang didapat diinginkan mampu memberi informasi penting dalam langkah meng-upgrade nilai dari belajar humas dan keprotokolan pada tiap-tiap jenjang pendidikan.

Dampak Kemandirian dari Belajar dan Sarana Prasarana Pembelajaran kepada nilai Belajar murid SMK Negeri 10 Surabaya. Kedua variabel independen dan dependen juga memiliki pengaruh. Dapat dilihat dari berbagai hasil peneliti, sesuai dengan hasil riset Mujisuciningtyas (2017) dengan cara parsial kemandirian ketika study dan sarana prasarana ketika pembelajaran berdampak signifikan kepada nilai dari study praktek murid. Sedangkan menurut Widodo (2017) kemandirian ketika study dan sarana perpustakaan dalam sekolah berdampak dengan simultan kepada nilai dari belajar praktek pengantar ekonomi dan bisnis kelas X1 di SMK Negeri 10 Surabaya.

Dari penjelasan yang telah diuraikan di atas, maka peneliti tertarik untuk menggunakan judul "Pengaruh Kemandirian Belajar dan Sarana Prasarana Pembelajaran Terhadap Hasil Belajar Siswa". Tujuan penelitian ini yaitu 1) peneliti mengetahui pengaruh kemandirian belajar terhadap hasil belajar, 2) peneliti mengetahui pengaruh sarana dan prasarana pembelajaran terhadap hasil belajar siswa, 3) peneliti mengetahui pengaruh kemandirian belajar dan sarana prasarana pembelajaran terhadap hasil belajar siswa.

dependen atau variabel terikat ialah hasil dari belajar siswa.

1. Jenis Penelitian

Riset ini memakai jenis riset kuantitatif memakai metode deskriptif. Pendekatan deskriptif menurut Sugiyono (2019) adalah "Metode deskriptif dipakai guna meneliti kepada populasi atau sampel-sampel yang ditentukan, proses pengumpulan dari data - data memakai instrumen riset, analisa data memiliki sifat kuantitatif/statistik, yang bertujuan guna menguji hipotesis yang sudah ditetapkan". 
Sumber dari data yang dipakai pada riset ini yakni:

a. Data primer merupakan data yang didapatkan langsung oleh peneliti. Hasil angket siswa digunakan sebagai data primer. Penyebaran angkat pada penelitian ini yaitu online.

b. Data sekunder yaitu data yang dihitung dengan tidak langsung oleh peneliti. Data sekunder ini berupa dokumentasi yaitu nilai ujian tengah semester siswa SMK Negeri 10 Surabaya.

Populasi dalam penelitian ini ditentukan berdasarkan Probability Sampling jenis sampel random sampling yaitu dimana objek yang akan diteliti dari anggota sampel dan populasi serta ditetapkan secara random dan tanpa melihat jenjang yang digunakan pada populasi (Sugiyono, 2019). Dengan demikian peneliti mengambil populasi sebesar 60 siswa dengan maka jumlah sampel adalah 52 siswa XI OTKP di SMK Negeri 10 Surabaya.

Hubungan penelitian pada penelitian ini dapat dikemukakan berdasarkan rancangan penelitian sebagai berikut :

Gambar 1. Rancangan Penelitian

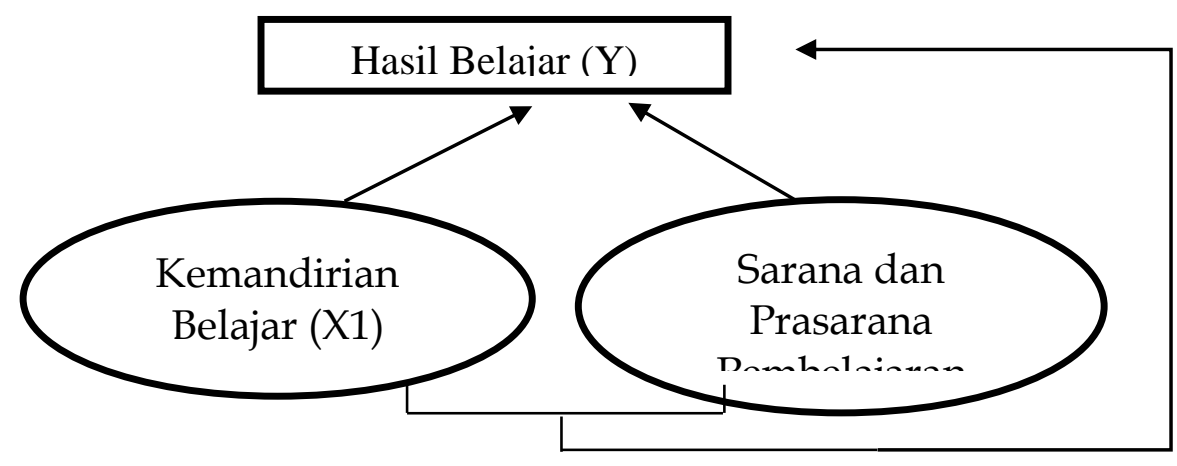

Berdasarkan gambar rancangan penelitian diatas, maka diberikan beberapa hipotesis diantaranya :

H1: Terdapat pengaruh yang signifikan antara kemandirian belajar terhadap hasil belajar siswa kelas XI SMK Negeri 10 Surabaya.

$\mathrm{H} 2$ : Terdapat pengaruh yang signifikan antara sarana dan prasarana pembelajaran belajar terhadap hasil belajar siswa kelas XI SMK Negeri 10 Surabaya.

H3: Terdapat pengaruh yang signifikan antara kemandirian belajar dan sarana prasarana pembelajaran terhadap hasil belajar siswa kelas XI SMK Negeri 10 Surabaya.

Adapun indikator variabel yang digunakan dalam penelitian ini untuk mengukur variabel kemandirian belajar menurut Mujisuciningtyas (2017) yaitu:

1. Memiliki perencanaan dalam belajar

2. Mandiri
3. Tanggung jawab

4. Disiplin

5. Inisiatif

6. Evaluasi diri

7. Kemampuan mengambil keputusan

8. Keinginan untuk maju

9. Keberanian menyelesaikan konflik diri sendiri

10. Aktif dalam KBM

Begitu juga indikator variabel yang digunakan dalam penelitian ini untuk mengukur variabel sarana dan prasarana pembelajaran menurut Motivasi et al (2017) yaitu:

1. Ketersediaan sarana dan prasarana pembelajaran.

2. Kualitas sarana dan prasarana pembelajaran.

3. Ruangan kelas yang digunakan terasa nyaman.

4. Keberfungsian perpustakaan.

5. Ketersediaan buku pelajaran. 
6. Penataan gedung sekolah.

Begitu juga indikator variabel yang digunakan dalam penelitian ini untuk mengukur variabel sarana dan prasarana pembelajaran menurut Motivasi et al (2017) yaitu:

1. Hasil Ujian Tengah Semester

1. Teknik Pengumpulan Data

a. Wawancara

Menggunakan Teknik ini dilakukan peneliti dengan wawancara secara langsung dengan narasumber yaitu guru mata pelajaran Humas dan Keprotokolan yaitu Ibu Sri Inah ,S.Pd., MM untuk menghubungkan pembelajaran Humas dan Keprotokolan dengan memperoleh informasi di sekolah SMK Negeri 10 Surabaya.

b. Dokumentasi

Tujuan dari teknik dokumentasi yaitu agar mendapatkan data keadaan murid, dan sarana prasarana serta hasil dari belajar yang digunakan dari riset guru, yaitu nilai hasil UTS ganjil tahun ajaran 2020/2021 di SMK Negeri 10 Surabaya.

c. Angket

Angket membahas mengenai pengaruh kemandirian pembelajaran dan sarana prasarana dalam pembelajaran pada nilai dari belajar siswa di mata pelajaran humas dan keprotokolan di SMK Negeri 10 Surabaya. Skala likert yang digunakan untuk menetapkan skor instrumen penelitian dengan gradasi dari sangat positif hingga sangat negative dalam skor $1,2,3,4,5$.

2. Teknik Analisis Data

a. Uji Validitas

Menurut (Ghazali I, 2009) yang menyimpulkan jika "uji validitas dipakai guna sebagai tolok ukur ukur sah, maupun valid atau tidak sebuah kuesioner. Sebuah kuesioner disimpulkan valid ketika pertanyaan kepada kuesioner dapat dipakai menggali hal yang akan dihitung melalui kuesioner tersebut". Riset ini memakai teknik uji validitas pada teknik analisis faktor yang menggunakan software SPSS 23. Menggunakan suatu item untuk menentukan keputusan layak atau tidaknya, umumnya dilakukan uji signifikansi koefisien korelasi dengan taraf signifikansi 0.05 , yang maknanya suatu item menjadi valid ketika mempunyai relasi signifikan kepada skor total.

b. Uji Reliabilitas

Ghazali (2009) menyimpulkan jika "reliabilitas adalah alat dipakai menjadi tolok ukur kuesioner yang menjadi indikator dari peubah atau konstruk". Jawaban dan pernyataan seseorang dapat dikatakan reliabel atau handal terhadap kuesioner ketika respon dan statement tersebut konsisten atau stabil sama dengan selama waktu ke waktu. Teknik uji reliabilitas yang dipakai di riset ini ialah teknik analisis dibantu software SPSS 23. Dalam program SPSS metode yang dipakai ialah teknik Cronbach's Alpha. Instrumen yang reliabel bila nilai Cronbach's Alpha lebih tinggi dibanding 0,60.

c. Uji Asumsi Klasik

1) Uji Normalitas

Distribusi dari sebuah data ketika mengikuti atau mendekati distribusi normal dapat diketahui melalui melakukan uji normalitas (Ghazali I, 2009). Pendekatan parametrik dipakai menganalisis statistik ketika data menyebar secara normal, sedangkan ketika data yang tidak menyebar normal maka memakai pendekatan nonparametrik. Pada riset ini memakai teknik uji kolmogorov-smirnov, yaitu Teknik uji normalitas yang paling dipakai, utamanya sesudah munculnya program statistik yang tersedia. 
2) Uji Multikolinearitas

Berperan untuk mengukur tingkat asosiasi (keeratan) melalui besaran koefisien korelasi (r) pada hubungan/pengaruh antar variabel bebas. Dasar pengambilan keputusan untuk mengetahui ada tidaknya multikolinearitas dalam model regresi dapat diketahui dari nilai toleransi dan nilai nilai variance inflation factor (VIF). Tolerance mengukur variabilitas bebas yang terpilih yang tidak dapat dijelaskan oleh variabel bebas (independen) lainnya. Jadi nilai tolerance rendah sama dengan nilai VIF tinggi (karena VIF $=1 /$ tolerance) dan menunjukkan adanya kolinearitas yang tinggi. Nilai cut off yang umum dipakai adalah nilai tolerance 0,01 atau sama dengan nilai VIF diatas 10 (Ghazali I, 2009).

3) Uji Heteroskedastisitas

Terjadinya Heteroskedastisitas ketika berbentuk pola yang teratur pada titiktitik scatterplot, baik menyempit, melebar, maupun menggelombang. Ketika titik pada scatterplot terjadi penyebaran di antara sumbu $\mathrm{Y}$, dan berbentuk pola yang tidak beraturan. Maka variabel bebas tersebut bersifat homoskedastisitas atau tidak terjadinya heteroskedastisitas (Ghazali I, 2009).

d. Analisis Regresi Linier Berganda Analisis regresi linier berganda dipakai ketika menentukan apakah ada dampak diantara sarana dan prasarana sekolah secara bersamaan antara hasil belajar siswa. Menentukan kontribusi variabel X1, X2 terhadap Y.
Dua Variabel Bebas : $Y=a+b 1 X 1+$ b2X2

Keterangan :

$\mathrm{Y}=$ Variabel dependen

$\alpha=$ konstanta

$\mathrm{b} 1 / \mathrm{b} 2=$ Koefisien regresi

$\mathrm{X} 1=$ Variabel (Kemandirian Belajar)

$\mathrm{X} 2$ = Variabel (Sarana dan Prasarana

Pembelajaran)

e. Uji Hipotesis

1) Uji T

Kegunaan Uji $t$ adalah guna mendapati beberapa variabel independen yang dengan cara parsial apakah memiliki dampak nyata atau tidak pada variabel dependen. Dengan menggunakan derajat signifikansi sebesar 0,05 .

2) Uji $F$

Menggunakan Uji $F$ ketika ingin memeriksa variabel dependen yang secara simultan apakah ada dampak yang signifikan pada variabel independen. Angka signifikansi yang dipakai ialah 0,05 . Bila nilai $F$ mendapatkan nilai hitung yang lebih tinggi dari nilai F-tabel artinya hipotesis alternatif yang menyimpulkan jika keseluruhan variabel independen dengan cara simultan berdampak signifikan pada variabel dependen.

3) Uji Koefisien Determinasi (R2) Dipakai memprediksi dan meninjau besaran dari keikutsertaan yang berdampak dengan memberikan variabel $\mathrm{X}$ dengan cara simultan (bersama-sama) kepada variabel $\mathrm{Y}$. 


\section{HASIL DAN PEMBAHASAN Statistik Deskriptif}

Statistik deskriptif dimaksudkan untuk mengetahui distribusi frekuensi persentase jawaban responden yang telah mengisi kuesioner yang sudah disebarkan ke responden mengenai kemandirian belajar, sarana dan prasarana pembelajaran dan hasil belajar siswa dengan jumlah responden sebesar 52 siswa. Besarnya nilai minimum kemandirian belajar sebesar 9 dengan nilai maksimal 45 serta nilai rata-ratanya (mean) sebesar 34,42 dari nilai penyimpangannya sebesar 5,05, nilai minimum sarana dan prasarana pembelajaran sebesar 4 dengan nilai maksimal 15 serta nilai rata-ratanya (mean) sebesar 12,13 dari nilai penyimpangannya sebesar 2,34 dan nilai minimum sebesar 55 dengan nilai maksimal sebesar 91 serta nilai rata-ratanya (mean) sebesar 76,92 dari nilai penyimpangannya sebesar 7,35 .

Tabel 1. Hasil Uji Statistik Deskriptif

\begin{tabular}{|c|c|c|c|c|c|}
\hline & $\mathrm{N}$ & Minimum & Maximum & Mean & Std. Deviation \\
\hline Kemandirian Belajar & 52 & 9 & 45 & 34,42 & 5,050 \\
\hline $\begin{array}{l}\text { Sarana Prasarana } \\
\text { Pembelajaran }\end{array}$ & 52 & 4 & 15 & 12,13 & 2,335 \\
\hline Hasil Belajar Siswa & 52 & 55 & 91 & 76,92 & 7,348 \\
\hline Valid N (listwise) & 52 & & & & \\
\hline
\end{tabular}

Sumber: Data Diolah Oleh Peneliti (2020)

\section{Uji Validitas}

Menurut Ghazali I (2009) suatu tes dapat dikatakan mempunyai validitas tinggi apabila tes tersebut menjalankan fungsi ukurnya, atau memberikan hasil ukur sesuai dengan makna dan tujuan diadakannya tes tersebut. Uji validitas berkenaan dengan tingkat kesesuaian antara definisi konseptual dengan definisi operasional dari variabel.

\section{Uji Reliabilitas}

Suatu alat ukur mempunyai reliabilitas yang tinggi atau dapat dipercaya jika alat ukur itu baik, dalam pengertian bahwa alat ukur tersebut stabil, dapat diandalkan dan dapat diramalkan (predictability). Ghazali I (2009) menyatakan bahwa koefisien Alpha Cronbach merupakan koefisien reliabilitas yang paling
Disebut valid apabila sebuah instrumen mampu mengukur apa yang diinginkan dan mengungkapkan data dari variabel yang diteliti secara tepat. Mengolah data dan didasari melalui SPSS 23 dapat dinyatakan bahwa instrumen penelitian dinyatakan valid. Ada 13 item pernyataan yang sudah diujikan dan sudah diolah uji validitasnya. Data dikatakan valid karena nilai signifikan $<0,05$.

umum yang dapat digunakan karena koefisien menggambarkan variasi dari item-item baik untuk format benar/ salah ataupun bukan. Suatu variabel dikatakan reliabel jika memberikan nilai Alpha Cronbach $>0,6$. Berdasarkan Tabel 2 menunjukkan hasil cronbach's alpha $>0,6$ maka instrumen riset dikatakan reliabel.

Tabel 2. Reliability Statistics

\begin{tabular}{cc}
\hline $\begin{array}{c}\text { Cronbach's } \\
\text { Alpha }\end{array}$ & N of items \\
\hline .773 & 34 \\
\hline
\end{tabular}

Sumber: Data Diolah Oleh Peneliti (2020) 


\section{Uji Normalitas}

Uji normalitas bertujuan untuk menguji apakah model regresi, variabel bebas dan variabel terikat keduanya memiliki distribusi normal ataukah tidaknya suatu data (Ghazali I, 2009). Data tersebut memperlihatkan jika nilai Asymp. Sig. (2tailed) mempunyai nilai $>0,05$ yang bisa diartikan jika berdistribusi normal karena $0,995>0,05$. maka dapat disimpulkan data tersebut berdistribusi normal, sehingga dapat digunakan dalam penelitian.

Tabel 3. Hasil Uji Normalitas

\begin{tabular}{llr}
\multicolumn{2}{c}{ One-Sample Kolmogorov-Smirnov Test } \\
\hline $\mathrm{N}$ & \multicolumn{2}{c}{ Unstandardized Residual } \\
& Mean & 52 \\
Normal Parameters, & 0E-7 \\
& Std. & 5,95722306 \\
& Deviation &, 058 \\
Most Extreme & Absolute &, 058 \\
Differences & Positive &,- 052 \\
Kolmogorov-Smirnov Z & Negative &, 416 \\
Asymp. Sig. (2-tailed) & &, 995 \\
\hline
\end{tabular}

Sumber: Data Diolah Oleh Peneliti (2020)

\section{Uji Multikolinearitas}

Uji Multikolinearitas Bertujuan untuk menguji apakah model regresi ditemukan adanya korelasi antar variabel bebas. Jika terjadi korelasi, maka terdapat problem multikolinearitas (Ghazali I, 2009). Berdasarkan hasil uji multikolinieritas dengan alat bantu komputer yang menggunakan

\section{Uji Heteroskedastisitas}

Berdasarkan gambar di atas letak bintik menyebar di sekitar angka 0 dan tidak hanya menempati satu tempat atau menyebar karena sebab itu tidak terjadi heteroskedastisitas pada penelitian ini. Dalam penelitian ini, uji heterokedastisitas dilakukan dengan metode yang digunakan yaitu
Program SPSS, hasil dari uji multikolinearitas dapat dijelaskan bahwa tidak terjadi multikolinearitas karena dapat dibuktikan bahwa nilai dari tolerance 0,804 yang artinya $>0,10$ dan hasil VIF 1,243 yang berarti $<10$. hingga bisa dinyatakan jika tidak ada gejala.

scatterplot, Pengambilan keputusan berupa (Ghazali I, 2009) :

1. Bila terdapat pola tertentu seperti titik-titik yang membentuk pola tertentu yang teratur, maka terjadi heteroskedastisitas.

2. Bila tak ada pola yang jelas seperti titik menyebar diatas dan dibawah angka 0 pada sumbu Y, maka tidak terjadi heteroskedastisitas.

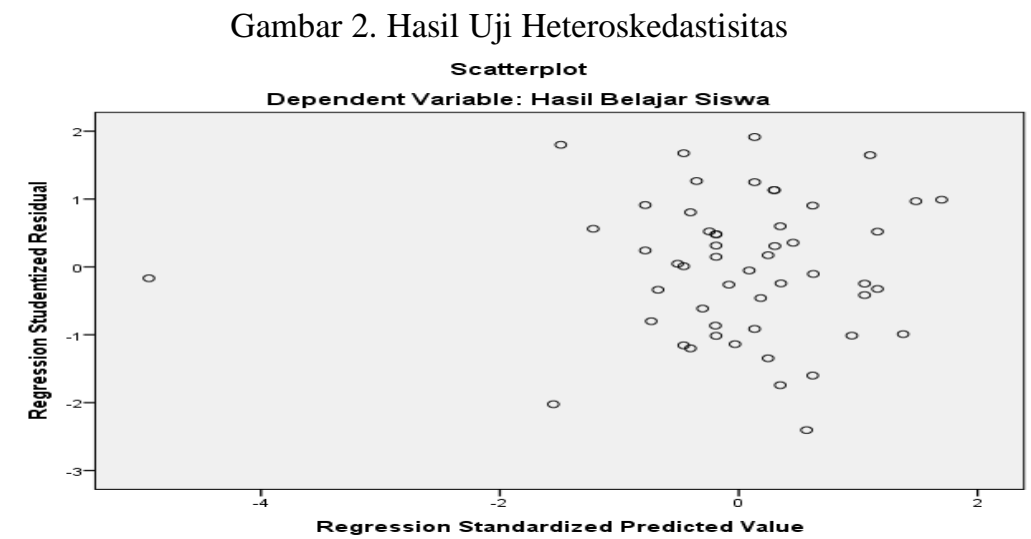

Sumber: Data Diolah Oleh Peneliti (2020) 


\section{Uji Analisis Regresi Linier Berganda}

Tabel 4 menunjukkan model persamaan regresi linear berganda yakni :

$\mathrm{Y}=\mathrm{a}+\mathrm{b}_{1} \mathrm{X}_{1}+\mathrm{b}_{2} \mathrm{X}_{2}+\mathrm{e}$

$\mathrm{Y}=46,849+0,462 \mathrm{X}_{1}+1,167 \mathrm{X}_{2}+\mathrm{e}$

1. Nilai koefisien konstanta sebesar $46,849 \mathrm{Hal}$ ini berarti bahwa jika variabel kemandirian belajar serta sarana dan prasarana belajar konstan, maka akan menaikkan variabel hasil belajar murid sebesar 46,849 .
2. Nilai koefisien $X_{1}$ sebesar 0,462 . Hal ini berarti bahwa setiap peningkatan variabel kemandirian belajar sebesar 1 persen, maka akan menaikkan variabel hasil belajar murid sebesar 0,462 .

3. Nilai koefisien $X_{2}$ sebesar 1,167 . Hal ini berarti bahwa setiap peningkatan variabel sarana dan prasarana sebesar 1 persen, maka variabel hasil belajar murid akan naik sebesar 1,167 .

Tabel 4. Uji Analisis Regresi Linier Berganda

\begin{tabular}{lccc}
\multicolumn{4}{c}{ Coefficients $^{\mathbf{a}}$} \\
& $\begin{array}{c}\text { Unstandardized } \\
\text { Coefficients }\end{array}$ & $\mathbf{t}$ & Sig. \\
& B & & \\
\hline (Constant) & 46,849 & 7,536 &, 000 \\
Kemandirian Belajar &, 462 & 2,460 &, 017 \\
Sarana Prasarana & 1,167 & 2,872 &, 006 \\
Pembelajaran & & &
\end{tabular}

Sumber: Data Diolah Oleh Peneliti (2020)

\section{Uji T}

Pada hasil uji t $\mathrm{X}_{1}$ nilai signifikansinya $0,017<0,05$ yang bisa diartikan jika hipotesis diterima, sehingga kemandirian belajar dapat memberikan pengaruh secara signifikan pada hasil belajar siswa. Serta hasil uji t pada $\mathrm{X}_{2}$ nilai signifikansinya $0,006<0,05$ yang bisa diartikan jika hipotesis diterima, maka sarana dan prasarana pendidikan dapat memberi dampak yang signifikan kepada hasil belajar siswa. Dapat disimpulkan bahwa secara parsial variabel $X^{1}$ dan $X^{2}$ memiliki pengaruh signifikan terhadap variabel $\mathrm{Y}$.

\section{Uji F}

Pada hasil uji f menunjukkan bahwa $0,012<0,05$ yang dapat diartikan bahwa hasil perhitungan itu signifikan dan hipotesis diterima. Hal ini berarti variabel bebas yang terdiri dari kemandirian belajar dan sarana dan prasarana belajar secara simultan mempunyai pengaruh signifikan terhadap variabel terikatnya yaitu hasil belajar murid.

\section{Koefisien Determinasi $\left(\mathbf{R}^{2}\right)$}

Pada hasil nilai dari pengujian koefisien determinasi didasari pada kolom $\mathrm{R}$ square menunjukkan nilai 0,343 . Yang dapat diartikan bahwa kontribusi variabel kemandirian dalam belajar dan variabel sarana prasarana dalam studi pada variabel nilai studi siswa sejumlah $34,3 \%$. Dan yang tidak diteliti pada penelitian ini tersisa pengaruh variabel lain yaitu sejumlah $65,7 \%, 65,7 \%$ dipengaruhi oleh variabel lain di luar variabel yang digunakan dalam penelitian ini. 


\section{PEMBAHASAN}

Berdasarkan nilai riset tentang kemandirian belajar $\left(\mathrm{X}_{1}\right)$ kepada nilai belajar siswa $(\mathrm{Y})$ memberikan hasil jika kemandirian belajar berdampak secara signifikan pada hasil belajar siswa SMK Negeri 10 Surabaya dengan uji hipotesis sebesar $0,017<0,05$ yang mempertunjukkan $\mathrm{H}^{1}$ diterima. Sedangkan hasil penelitian mengenai sarana dan prasarana pembelajaran (X2) pada hasil belajar siswa $(\mathrm{Y})$ menunjukkan nilai jika sarana dan prasarana dalam pembelajaran berdampak signifikan pada hasil belajar murid SMK Negeri 10 Surabaya dengan uji hipotesis sebesar 0,006 < 0,05 yang mempertunjukkan $\mathrm{H}^{1}$ diterima.

\section{a) Pengaruh Kemandirian Belajar Terhadap Hasil Belajar Siswa}

Berdasarkan penelitian yang telah dilakukan variabel $X_{1}$ nilai signifikansinya $0,017<0,05$ yang bisa diartikan jika hipotesis diterima, sehingga kemandirian belajar dapat memberikan pengaruh secara signifikan pada hasil belajar siswa. Hal tersebut dibuktikan dengan adanya penelitian dari Prayuda et al., (2014) yang menyatakan bahwa Kemandirian belajar memiliki pengaruh terhadap hasil belajar siswa pada mata pelajaran ekonomi kelas XI IIS SMA Negeri 4 Pontianak. Dalam variabel kemandirian belajar, siswa cenderung merespon baik dalam menjawab pernyataan yang diberikan, hal ini dapat dilihat dari hasil kuisioner, dengan skor rata-rata dari masingmasing indikator pernyataannya dalam kategori tinggi, maka dapat disimpulkan tingginya pendapat yang diberikan responden dalam menjawab kuesioner pada pernyataan indikator kemandirian belajar menunjukkan bahwa siswa kelas XI SMK Negeri 10 Surabaya bidang pengantar ekonomi dan bisnis dapat dikatakan telah memiliki kemandirian belajar yang baik.

Hasil penelitian ini mendukung penelitian Akbar (2015). Menurut Akbar (2015), dalam penelitiannya mengemukakan bahwa kemandirian belajar berpengaruh signifikan terhadap prestasi belajar siswa Madrasah Aliyah Kab. Kudus. Di dalam penelitian Faisal et al., (2019) terdapat pengaruh tingkat kemandirian belajar terhadap hasil belajar Biologi peserta didik kelas XII MIA SMA Negeri 16 Makassar. Sedangkan menurut penelitian Saragih (2017) mengenai pengaruh kemandirian pada hasil belajar menunjukkan bahwa kemandirian berpengaruh signifikan positif pada hasil belajar.

\section{b) Pengaruh Sarana dan Prasarana Pembelajaran Terhadap Hasil Belajar Siswa}

Berdasarkan penelitian yang telah dilakukan variabel $\mathrm{X}_{2}$ nilai signifikansinya $0,006<0,05$ yang bisa diartikan jika hipotesis diterima, maka sarana dan prasarana pendidikan dapat memberi dampak yang signifikan kepada hasil belajar siswa. Dalam variabel sarana dan prasarana belajar, siswa cenderung merespon baik dalam menjawab pernyataan yang diberikan, hal ini dapat dilihat dari hasil kuisioner, dengan skor ratarata dari masing-masing indikator pernyataannya dalam kategori tinggi, maka dapat disimpulkan tingginya pendapat yang diberikan responden dalam menjawab kuesioner pada pernyataan indikator kemandirian belajar menunjukkan bahwa siswa kelas XI SMK Negeri 10 Surabaya bidang pengantar ekonomi dan bisnis dapat dikatakan telah memiliki sarana dan prasarana belajar yang baik. Hasil penelitian ini mendukung penelitian Alfaruq (2020). Hal tersebut dibuktikan dengan adanya penelitian terdahulu yaitu Alfaruq et al., (2020) ada pengaruh positif Sarana prasarana bengkel (X) terhadap Hasil belajar siswa TKR SMK Tunas Bangsa Mijen. Menurut penelitian Studi et al (2015) bahwa pengaruh sarana dan prasarana terhadap hasil belajar siswa adalah positif dan signifikan. Di dalam penelitian Praktik et al., (2015) mengemukakan bahwa terdapat pengaruh positif dan signifikan antara sarana praktik terhadap hasil belajar. Sedangkan menurut Widodo (2017) ada pengaruh sarana perpustakaan sekolah terhadap hasil belajar 
praktek pengantar ekonomi dan bisnis kelas XI di SMK Negeri 10 Surabaya.

\section{c) Pengaruh Kemandirian Belajar dan Sarana Prasarana Pembelajaran Terhadap Hasil Belajar Siswa}

Berdasarkan penelitian yang telah Pada hasil uji f menunjukkan bahwa 0,012 < 0,05 yang dapat diartikan bahwa variabel $\mathrm{X}$ berpengaruh signifikan secara simultan terhadap Y. Hal ini berarti variabel bebas yang terdiri dari kemandirian belajar dan sarana dan prasarana belajar secara simultan mempunyai pengaruh signifikan terhadap variabel terikatnya yaitu hasil belajar murid. Tingginya nilai ini diperoleh siswa dari hasil belajar praktik. Sebagian besar siswa mendapatkan nilai dengan kategori baik. Dengan kategori ini disimpulkan bahwa siswa mengerjakan tugas yang dibebankan dapat dilaksanakan dengan lancar dengan kesalahan kesalahan kecil, mutu tinggi dalam pembelajaran. Bahkan ada sebagian siswa yang mendapatkan nilai dengan kategori sangat baik. Dengan kesimpulan bahwa siswa mengerjakan tugas yang dibebankan dapat dilaksanakan dengan baik, mutu hasil belajar, dan merupakan mutu paling tinggi dalam hasil belajar siswa. Hal ini menunjukkan bahwa siswa kelas XI SMK Negeri 10 Surabaya bidang pengantar ekonomi dan bisnis dapat dikatakan telah memiliki kemandirian belajar dan sarana dan prasarana belajar yang baik.

Hasil penelitian ini mendukung penelitian Widodo (2017). Berdasarkan hasil penelitian Widodo (2017) tentang dampak kemandirian dalam proses belajar kepada nilai belajar praktek pengantar ekonomi dan bisnis menyimpulkan kemandirian study berdampak pada nilai belajar praktek pengantar ekonomi dan bisnis. Sedangkan menurut Faisal et al., (2019) ada dampak kemandirian dalam proses study dan pemaksimalan fasilitas dari belajar kepada nilai belajar dari biologi murid kelas XII MIA di SMAN 16 Makassar. Didukung juga oleh Alfaruq et al., (2020) pada penelitiannya juga menyatakan yang sama yaitu adanya dampak positif sarana prasarana bengkel kepada hasil belajar murid TKR SMK Tunas Bangsa Mijen. Dapat dilihat dari berbagai hasil peneliti, sesuai dengan hasil riset Mujisuciningtyas (2017) dengan cara parsial kemandirian ketika study dan sarana prasarana ketika pembelajaran berdampak signifikan kepada nilai dari study praktek murid.

\section{SIMPULAN}

Sesuai dengan pembahasan dan nilai penelitian yang diperoleh, mampu ditarik kesimpulan bahwa. Kemandirian belajar siswa berdampak signifikan pada nilai belajar yang dilihat dari hasil uji $\mathrm{T}$ pada $\mathrm{X}^{1}$ yaitu sebesar $0,017<0,05$ yang bisa diartikan hipotesis diterima. Sarana dan prasarana pembelajaran berdampak signifikan pada nilai belajar yang dilihat dari uji $\mathrm{T}$ pada $\mathrm{X}^{2}$ yaitu sebesar 0,006 < 0,05 yang dapat diartikan hipotesis diterima.

Adapun Saran yang diajukan penulis sebagai berikut: Siswa SMK Negeri 10 Surabaya disarankan agar lebih mandiri, berani dalam bertindak, lebih percaya akan kemampuan yang dimiliki, dan bisa merawat sarana prasarana agar bisa digunakan lebih lama serta dapat digunakan dengan layak. Peneliti mempunyai batasan penelitian yaitu hanya memakai populasi sebesar 60 siswa dan sampel sebesar 52 siswa dan menggunakan populasi dan sampel hanya di SMK Negeri 10 Surabaya. 
Qomariyah \& Wulandari, Pengaruh Kemandirian Belajar...153

\section{DAFTAR RUJUKAN}

Akbar, R. F. (2015). Pengaruh Metode Mengajar Guru dan Kemandirian Belajar terhadap Prestasi Belajar Siswa Madrasah Aliyah Kab. Kudus. Inferensi, $\quad 6(2), \quad 225$. https://doi.org/10.18326/infsl3.v8i1.225 $-243$

Alfaruq, S. M., Achmad, N., \& Mahendra, S. (2020). Pengaruh Sarana Prasarana Bengkel terhadap Hasil Belajar Siswa Teknik Kendaraan Ringan. Journal of Vocational Education and Automotive Technology, 1(1), 30-35.

Balapumi, R., \& Aitken, A. (2012). Concepts and factors influencing independent learning in IS higher education. ACIS 2012: Proceedings of the 23rd Australasian Conference on Information Systems, 1-10.

CHENG, C. (2011). The Role of SelfRegulated Learning in Enhancing Learning Performance. May.

Chepkonga, M. C. (2017). Influence of Learning Facilities on Provision of Quality Education in Early Childhood Development Centres in Kenya. International Journal of Education and Research, 5(6), 15-26.

Faisal, M., Rapi, M., \& Damayanti, E. (2019). Pengaruh Tingkat Kemandirian Belajar dan Pemanfaatan Fasilitas Belajar terhadap Hasil Belajar Biologi Peserta Didik. Jurnal Al-Ahya, 1(3), 26-35.

Firdausy, A. R., Setyaningsih, N., Ishabu, L. S., \& Waluyo, M. (2019). The Contribution of Student Activity and Learning Facilities to Learning Independency and Its Impact on Mathematics Learning Outcomes in Junior High School. IJOLAE Indonesian Journal on Learning and Advanced Education, 1(2), 29-37. https://doi.org/10.23917/ijolae.v1i2.810 4

Ghazali I. (2009). Aplikasi Analisis Multivariate Dengan Program SPSS. (Edisi Keem). Universitas Diponegoro.

Ilomo, O., \& Mlavi, B. (2016). The Availability of Teaching and Learning Facilities and Their Effects on Academic Performance in Ward Secondary Schools in Muheza Tanzania. International Journal of Educational Research, 4(6), 571-582. www.ijern.com

Sari, A. K., Muhsin, dan Rozi, F. (2017). Pengaruh Motivasi, Sarana Prasarana, Efikasi Diri, dan Penyesuaian Diri terhadap Kemandirian Belajar. Economic Education Analysis Journal, 6(3), 923-935.

Mujisuciningtyas, N. (2017). Pengaruh Kemandirian Belajar dan Sarana Prasarana Pembelajaran terhadap Hasil Belajar Praktik di SMK Negeri 2 Tuban. Jurnal Ekonomi Pendidikan dan Kewirausahaan, 2(1), 103. https://doi.org/10.26740/jepk.v2n1.p10 3-115

Mulyono, D. (2017). The Influence of Learning Model and Learning Independence on Mathematics Learning Outcomes by Controlling Students' Early Ability. International Electronic Journal of Mathematics Education, 12(3), 689-708. https://www.iejme.com/download/theinfluence-of-learning-model-andlearning-independence-onmathematics-learning-outcomes-by.pdf

Othman, N., \& Leng, K. B. (2011). The Relationship between Self-Concept, Intrinsic Motivation, SelfDetermination and Academic Achievement among Chinese Primary School Students. International Journal of Psychological Studies, 3(1), 90-98. 
https://doi.org/10.5539/ijps.v3n1p90

Aini, S. N., Sudira, P. (2015). Pengaruh Strategi Pembelajaran, Gaya Belajar, Patiseri SMK Se-Gerbangkertasusila. Jurnal Pendidikan Vokasi, 5 (1) 88102.

Prayuda, R., Thomas, Y., \& Basri, M. (2014). Pengaruh Kemandirian Belajar terhadap Hasil Belajar Siswa pada Mata Pelajaran Ekonomi di SMA. British Journal of Psychiatry, 205(01), 76-77. https://www.cambridge.org/core/produ ct/identifier/S0007125000277040/type/ journal_article

Purwanto. (2008). Evaluasi Hasil Belajar. Pustaka Belajar.

Saragih, D. K. (2017). Pengaruh Kemandirian, Gaya Belajar Dan Lingkungan Belajar Terhadap Hasil Belajar Akuntansi Siswa Kelas X Program Keahlian Akuntansi SMK PGRI 3 Sidoarjo. Jurnal Ekonomi Pendidikan dan Kewirausahaan, 2(1), 29.

https://doi.org/10.26740/jepk.v2n1.p2941

Sobandi, A., Yuniarsih, T., Rasto, \& Adman. (2020). Learning Facilities: Can It improve the Vocational School Productivity? Journal of Educational and Social Research, 10(4), 146-155. https://doi.org/10.36941/jesr-20200074

Sugiyono. (2019). Metode Penelitian
Kuantitatif, Kualitatif, dan $R \& D$. Alfabeta.

Suratman, B., Wulandari, S. S., Nugraha, J., \& Narmaditya, B. S. (2020). Does Teacher Certification Promote Work Motivation and Teacher Performance? A Lesson from Indonesia. International Journal of Innovation, Creativity and Change, 11(10), 516-525.

Sutrisno, V. L. P., \& Siswanto, B. T. (2016). Faktor-Faktor Yang Mempengaruhi Hasil Belajar Siswa pada Pembelajaran Praktik Kelistrikan Otomotif SMK di Kota Yogyakarta. Jurnal Pendidikan Vokasi, $6(1)$ 111. https://doi.org/10.21831/jpv.v6i1.8118

Widiartini, N. K., \& Sudirtha, I. G. (2019). Effect of KWL Learning Method (know-want-learn) and self-assessment on student learning independence Vocational high school. International Journal of Social Sciences and Humanities, 3(2), 277-284. https://doi.org/10.29332/ijssh.v3n2.331

Widodo, S. (2017). Pengaruh Kemandirian Belajar dan Sarana Perpustakaan Sekolah terhadap Hasil Belajar Praktek Pengantar Ekonomi dan Bisnis Di SMK Negeri 10 Surabaya. Jurnal Ekonomi Pendidikan dan Kewirausahaan, 4(2), 214. https://doi.org/10.26740/jepk.v4n2.p21 4-224. 